\title{
Subglacial landforms beneath Rutford Ice Stream, Antarctica: detailed bed topography from ice-penetrating radar
}

\author{
Edward C. King, Hamish D. Pritchard, and Andrew M. Smith \\ British Antarctic Survey, Madingley Road, Cambridge, UK \\ Correspondence to: E. C. King (ecki@bas.ac.uk)
}

Received: 15 October 2015 - Published in Earth Syst. Sci. Data Discuss.: 12 November 2015

Revised: 16 February 2016 - Accepted: 10 March 2016 - Published: 6 April 2016

\begin{abstract}
We present a digital elevation model of the bed of Rutford Ice Stream, Antarctica, derived from radioecho sounding data. The data cover an $18 \times 40 \mathrm{~km}$ area immediately upstream of the grounding line of the ice stream. This area is of particular interest because repeated seismic surveys have shown that rapid erosion and deposition of subglacial sediments has taken place. The bed topography shows a range of different subglacial landforms including mega-scale glacial lineations, drumlins and hummocks. This data set will form a baseline survey which, when compared to future surveys, should reveal how active subglacial landscapes change over time. These data also allow comparison between subglacial landforms in an active system with those observed in deglaciated areas in both polar regions. The data set comprises observed ice thickness data, an interpolated bed elevation grid, observed surface elevation data and a surface elevation grid. The data set is available at http://doi.org/269.
\end{abstract}

\section{Introduction}

Subglacial bedforms develop where ice flows over a sedimentary substrate, but precisely how this happens is still the subject of much research (e.g. Clark, 2010; Menzies, 1989; Rose, 1987; Fowler, 2010). The size and shape of large numbers of palaeo-landforms have been mapped from exposed former ice sheet beds by satellite, airborne and shipboard systems (e.g. Clark et al., 2009; Greenwood and Clark, 2010; Spagnolo et al., 2012), but accessing the bed of contemporary ice sheets for such studies is extremely difficult. While the basal topography beneath the Antarctic Ice Sheet is becoming better known at a spatial resolution of kilometres (Fretwell et al., 2013), there have been only a small number of surveys that provide spatial resolution of several metres that are hence capable of showing the size and distribution of subglacial landforms (King et al., 2007, 2009). These surveys have so far concentrated on Rutford Ice Stream, West Antarctica.

Rutford Ice Stream drains ice from the region of the Ellsworth Mountains into the Ronne Ice Shelf (Fig. 1; King,
2009). In common with other ice streams, the surface slopes along the ice stream are low, which means the basal driving stress is low. Therefore, in order to flow at circa $400 \mathrm{~m} \mathrm{a}^{-1}$ the resistance to flow provided by the bed must also be low (MacAyeal et al., 1995; Joughin et al., 2004). This implies the widespread presence of soft, unconsolidated, water-saturated sediments at the bed. Such sediments were first confirmed beneath Rutford Ice Stream using seismic surveying (Smith, 1997b; Smith and Murray, 2009), which also showed that the sediments were formed into elongate bedforms. The data set presented by King and co-authors used ice-penetrating radar to extend the mapping around the seismic lines to identify a suite of mega-scale glacial lineations (MSGLs). While extensive areas of MSGLs have been mapped in formerly glaciated areas (e.g. Stokes and Clark, 2002; Storrar and Stokes, 2007; Larter et al., 2009), this was the first time MSGLs were mapped beneath actively flowing ice at a similar 3-D resolution to offshore swath bathymetry. That data set was extended in the 2008-2009 Antarctic field season by further ground radar survey, covering an additional $25 \mathrm{~km}$ of the ice stream towards the grounding line. The combined data set covers a 


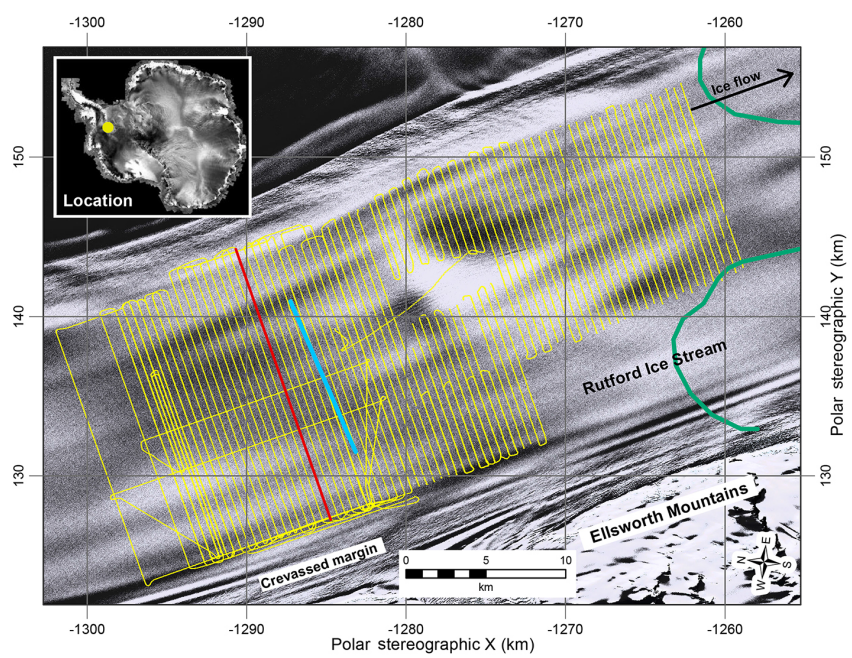

Figure 1. Location map. Rutford Ice Stream flows towards the south-east past the Ellsworth Mountains at between 365 and $400 \mathrm{~m} \mathrm{a}^{-1}$. Radar survey lines shown in yellow. Lines are spaced $500 \mathrm{~m}$ apart. Gaps in the coverage are due either to equipment failure or the need to avoid crevasses. The grounding line is shown in green. Location of profile line shown in Fig. 2 marked in red. Location of line C1 from Smith and Murray (2009) shown in blue. Polar stereographic projection. Axes are kilometres from South Pole.

$40 \times 18 \mathrm{~km}$ section of the bed, representing about $20 \%$ of the fast-flowing part of the ice stream (that portion flowing at more than $100 \mathrm{~m} \mathrm{a}^{-1}$ ). In this paper, we present the combined data set as a digital elevation model (DEM) of the bed which has grid dimensions of $100 \times 25 \mathrm{~m}$. The DEM provides the opportunity to compare the metrics of landforms beneath an active ice stream with those from palaeo-ice-stream beds; it also sets the context for more detailed seismic and radar studies of Rutford Ice Stream. The DEM will also act as a planning tool for bed-access drilling for sampling of substrate materials and measurement of basal conditions, as well as a baseline survey for the assessment of ongoing erosion and deposition by repeat surveys in the future.

\section{Location and previous work}

Rutford Ice Stream has been the site of considerable investigation over the past 3 decades. The downstream portion of the ice stream occupies a $26 \mathrm{~km}$ wide, $2.4 \mathrm{~km}$ deep trough adjacent to the Ellsworth Mountains (Fig. 1). Repeated seismic reflection profiling (Smith, 1997a, 2007; Smith et al., 2007; Smith and Murray, 2009) showed that the bed of the ice stream is composed of a mixture of soft and stiff till; that the soft till was formed into elongate landforms; and that erosion and deposition of the basal sediment took place over short timescales. In one location (Fig. 1) an area $500 \mathrm{~m}$ across was eroded by $6 \mathrm{~m}$ in the 6-year interval between seismic surveys (Smith op cit); over the following 7 years a mound of sediment $100 \mathrm{~m}$ across and $10 \mathrm{~m}$ high was emplaced in the same location. In addition, the acoustic characteristics of sections of the till changed over the period, indicating a transition from a soft, dilatant till to a stiff, lodged condition.

A radar survey of the bed topography surrounding the Smith (1997a, b) seismic lines, revealed a large suite of drumlins and MSGLs located in areas where the seismic surveys indicated soft, highly dilated, water-saturated sediment beneath the ice (King et al., 2009). Conversely, in areas where the seismic data indicated stiff till, the glacial landforms were much smaller, hummocky shapes. Over these hummocky areas, seismic recorders registered more microearthquakes from the bed of the ice stream (indicative of stick-slip motion) than in areas where the soft, wet sediment was present (Smith, 2006), which were seismically "quiet" (thought to equate to a more continuous style of movement due to the greater lubrication of the bed). This was a further indication that basal resistance to flow can vary spatially on a small scale, potentially leading to a shifting pattern of lubricated and sticky spots within the bed of the ice stream.

The ice surface flow velocity over the area of the radar survey is $365 \mathrm{~m} \mathrm{a}^{-1}$ at the upstream end, accelerating to $400 \mathrm{ma}^{-1}$ at the grounding line (Gudmundsson, 2006). There is a modulation of the flow speed at the grounding line of up to $20 \%$ with a fortnightly periodicity linked to the spring-neap tidal cycle (Gudmundsson, 2006). There was no significant variation in the flow speed of the ice stream over the 1979-2003 period (Gudmundsson and Jenkins, 2009).

\section{Data acquisition, processing and visualisation}

\subsection{Acquisition}

The bed elevation data were derived from ground-based radar surveys. The radar data were collected over two field seasons using the British Antarctic Survey's Deep Look Radio Echo Sounder (DELORES), operating at $3 \mathrm{MHz}$ (King et al., 2009). This is a monopulse radar operating in the $1-4 \mathrm{MHz}$ range that is based on designs developed by the University of Washington (Gades, 1998) and St Olaf College (Welch and Jacobel, 2003). The transmitter fires a $\pm 2500 \mathrm{~V}$ pulse into the antenna at a variable firing rate between 1 and $5 \mathrm{kHz}$. The antennae were resistively loaded wire dipoles, and the receiver used a chassis computer with a $100 \mathrm{MHz}$ digitising card. The surveys reported here were acquired using $20 \mathrm{~m}$ half-dipole antennas, which results in a centre frequency of approximately $3 \mathrm{MHz}$. The transmitter was fired at a pulse repetition rate of $1 \mathrm{kHz}$, and 1000 shots were stacked in the oscilloscope buffer to form each recorded trace in order to improve the signal-to-noise ratio. A trigger pulse was transmitted between transmitter and the receiving digitiser via a fibre-optic cable. The radar equipment was towed behind a snowmobile travelling at about $12 \mathrm{~km} \mathrm{~h}^{-1}$; therefore each trace of the final record is built up of data acquired over a horizontal distance of circa $3 \mathrm{~m}$. 
Each survey took a two-person team about 3 weeks to acquire. Navigation along the pre-planned lines was done using single-frequency GPS units mounted on the snowmobiles. A dual-frequency GPS receiver was operated on the recording sledge to provide accurate post hoc positions. Lines were oriented orthogonal to the ice flow, spaced $500 \mathrm{~m}$ apart. Some lines were acquired parallel to ice flow in order to check for any triggering discrepancies that could induce time shifts in the picked bed profiles. Surface crevassing in the ice stream margins limited the lateral coverage, and a zone of crevasses overlying the highest point in the bed topography resulted in a gap in coverage in the middle of the survey (Fig. 1).

\subsection{Processing}

The radar data were processed using ReflexW software (Sandmeier Scientific Software) in the following sequence:

- Assign positioning information. The dual-frequency GPS data were processed using the kinematic-mode precise point positioning service provided by the Canadian Geodetic Service (http://webapp.geod.nrcan.gc.ca/ geod/tools-outils/ppp.php). An offset was applied from the GPS antenna position (on the recording sledge) to the centre point of the antenna array to provide the geographic location of the reflection point on the bed.

- Suppression of the effects of the direct (airwave + groundwave) arrival. The direct arrival is a very high amplitude pulse transmitted horizontally between the transmitting and receiving antennae. The effect on the receiving system is to induce "wow" in the amplifier, that is, a high-amplitude, very low frequency overprint on the signal. Wow can be removed either by use of a frequency filter or by computing an average trace for the record and subtracting the average trace from each individual trace. The use of a bandpass filter on highamplitude signals can result in unwanted artefacts, particularly at the start and end of the record, so the average trace subtraction method was used here.

- Bandpass filter. Frequencies below $0.5 \mathrm{MHz}$ and above $10 \mathrm{MHz}$ were suppressed to increase the signal-to-noise ratio.

- Amplitude correction. The amplitudes were scaled proportional to the two-way travel time to compensate for the spherical spreading of the radar wave front.

- Migration. The action of the migration step is to reassign energy back to its source point; it has the effect of collapsing hyperbolae, correcting dipping events to true dip and improving horizontal resolution.

Figure 2a shows an example radar profile, displaying only that part of the record centred around the bed return. The display has high vertical exaggeration $(7.5: 1)$ to emphasise the

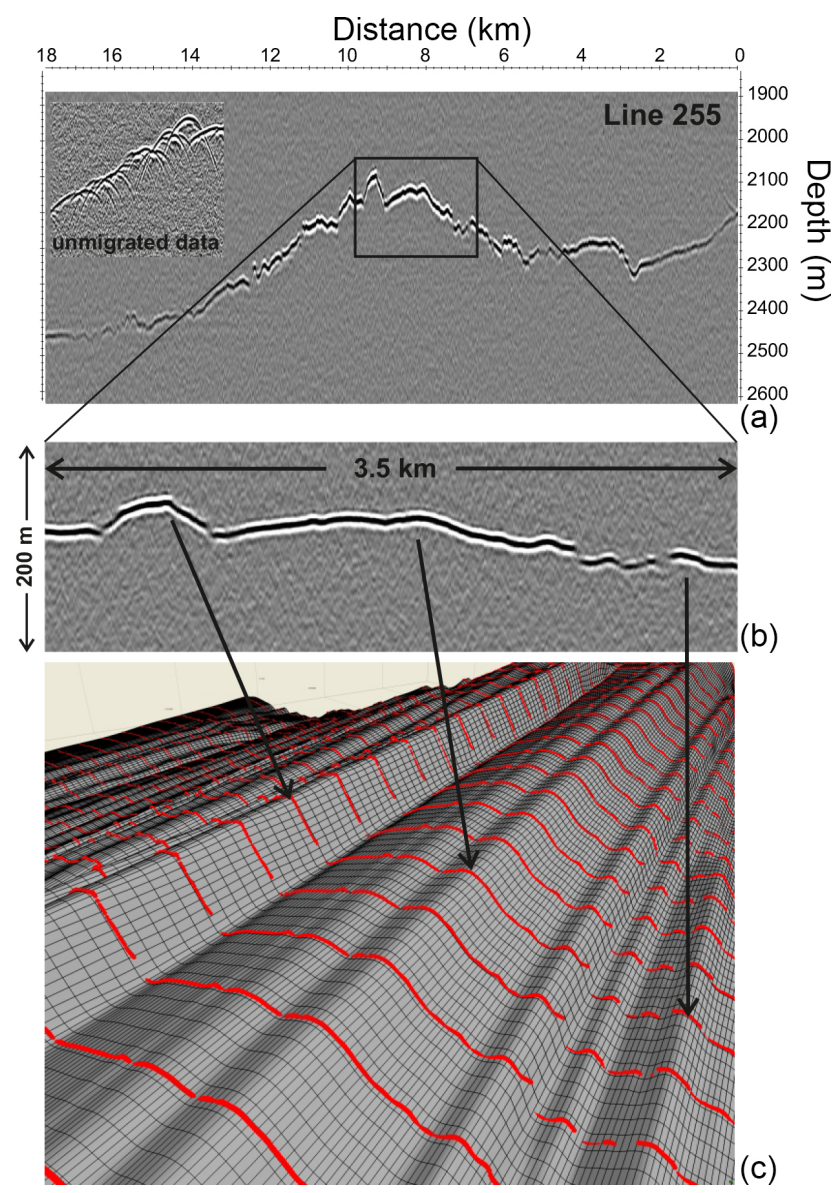

Figure 2. Detail of radar data. (a) Portion of radar profile across Rutford Ice Stream, windowed around the ice-sediment interface. Insert shows a portion of the data before the migration processing step. (b) Close-up of interface reflection. The reflection is a negative-positive-negative wavelet (white-black-white on the greyscale record) with a very high signal-to-noise ratio which allows very precise determination of the travel time. (c) 3-D view of the data (red lines) and interpolated grid (black lines) which shows the coherence of the picked data from line to line and shows that the gridded data faithfully reproduce the observed data.

shape of the landforms. The dominant event is the reflection from the bed of the ice stream. There is a very high degree of spatial correlation between each line (red lines in Fig. 2c).

The onset time of the bed reflection was determined at $7.5 \mathrm{~m}$ intervals along each line and converted to bed elevations with a precision of $\pm 3 \mathrm{~m}$. The bed is an interface with a much higher reflection coefficient than any nearby internal ice layers, so the precision of the radar range measurement is not affected by ambiguity in resolving the bed reflection from other reflections. The criteria that determine the precision of the range measurement are the rise time of the source signal; the bandwidth of the system; and the digitisation interval. Here we assume that there is no change in the wave speed profile between two adjacent measurements. In our system 


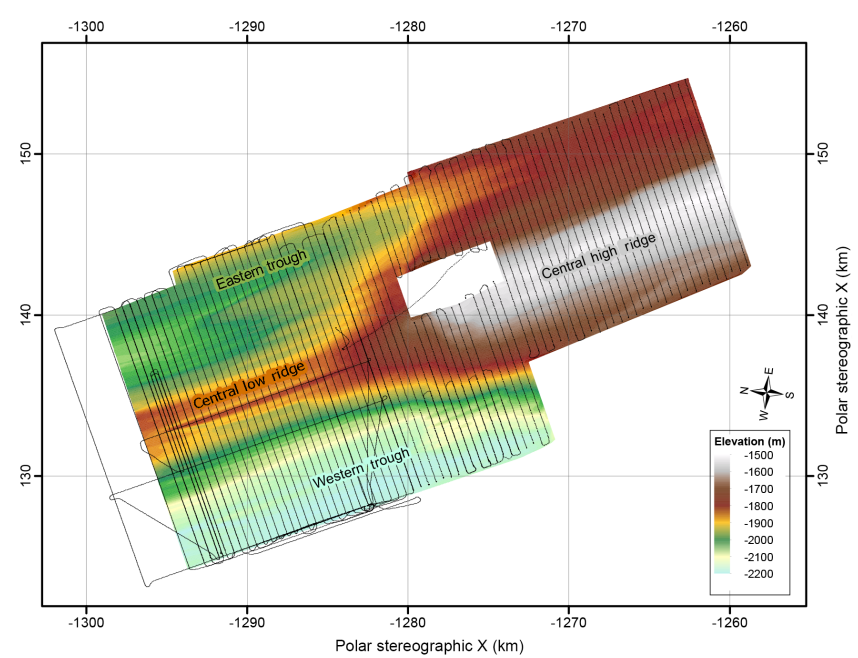

Figure 3. Map of bed elevation, referenced to the WGS84 ellipsoid. The difference between the ellipsoid and mean sea level is not known in this region. The bed of the ice stream has a $\mathrm{W}$ profile with a central ridge and troughs to either side. The downstream portion of the central ridge is several hundred metres higher than the surroundings and is likely to be a bedrock outcrop. Labels refer to features described in the text.

the output voltage rises at $250 \mathrm{Vns}^{-1}$; therefore the peak voltage is reached in $10 \mathrm{~ns}$, and the onset of the direct wave can be picked at the digital resolution which is $10 \mathrm{~ns}$ (i.e. the digitiser card samples the waveform at $10 \mathrm{~ns}$ intervals). The bandwidth of the recording system is $50 \mathrm{MHz}$, with the result that reflections from high-contrast interfaces such as the bed have sharp onsets that can be easily picked for time of arrival. The remainder of the error budget for the bed elevation is made up of uncertainty in the GPS-derived elevation of the recording system and uncertainty in the depth-averaged wave velocity.

The horizontal resolution is a measure of the minimum size an object has to be to be distinguishable as a separate entity on the target of interest. The size of the Fresnel zone at quarter wavelength is sometimes used as an estimate of horizontal resolution in radar data, but that measure is only valid for unmigrated data (Yilmaz, 1987). Migration collapses the size of the Fresnel zone to approximately one quarter of the dominant wavelength (Lindsey, 1989). Thus, the theoretical horizontal resolution of these migrated data is given by

$F_{\mathrm{d}}=V_{\mathrm{avg}} / 4 f$

where $F_{\mathrm{d}}$ is the post-migration Fresnel diameter, $V_{\text {avg }}$ is the average wave speed from surface to bed and $f$ is the frequency. For $V_{\text {avg }}=0.167 \mathrm{~m} \mathrm{~ns}^{-1}$ and the mean bandwidth frequency of $4.75 \mathrm{MHz}, F_{\mathrm{d}}=8.8 \mathrm{~m}$, comparable with the horizontal trace spacing of $7.5 \mathrm{~m}$.

The final step in the processing sequence was to convert the processed radar data to SEG-Y format to facilitate ex-

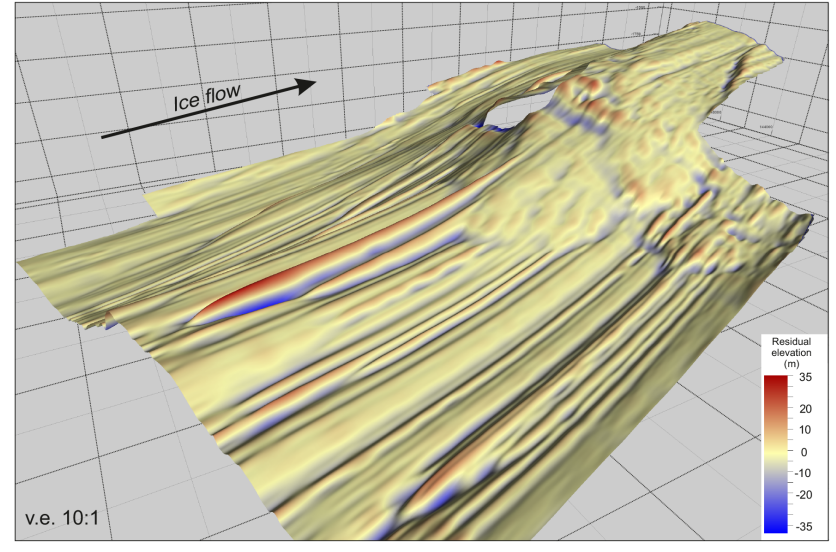

Figure 4. 3-D view of the gridded data set. View is downstream towards the south-east; vertical exaggeration is approximately 10 to 1 . The bed elevation surface has been colour-coded by residual elevation to emphasise the landforms. Residual elevation was computed by differencing the bed elevation surface with a smoothed version which used a $2 \mathrm{~km} \times 2 \mathrm{~km}$ spatial smoothing filter. Bold grid lines are spaced $4 \mathrm{~km}$ apart in the horizontal directions and $250 \mathrm{~m}$ apart in the vertical direction.

change of the data and import into interpretation software packages.

\subsection{Picking the bed reflector and visualisation}

The processed radar data files were imported into the Petrel Schlumberger ${ }^{\mathrm{TM}}{ }^{\text {interpretation software package. The times }}$ of the reflections from the bed of the ice stream were picked on the radar profiles using a semi-automatic picker that followed the peak of the reflection wavelet from trace to trace. This created a raw data set in $x, y, t$ form, where $x$ and $y$ were the coordinates in South Polar stereographic projection and $t$ was the two-way travel time. The measured point values were then interpolated onto a $25 \mathrm{~m}$ (cross-flow) $\times 100 \mathrm{~m}$ (along-flow) grid oriented orthogonal to the profile lines using a natural-neighbour algorithm with a $5: 1$ anisotropy ratio aligned along the ice flow direction (Fig. 2c). This interpolation scheme preserves the continuity of features elongate in the flow direction while preserving the high spatial sampling of the cross-flow bed profile.

The radar system determines the time of flight of the radio wave from the transmitter to the receiver via a reflection from the bed. This information was converted into elevation of the bed with respect to the WGS84 ellipsoid by using a timeto-depth conversion and then subtracting the depths from the surface elevation as recorded by the dual-frequency GPS system mounted on the recording sledge. The radar wave speed used for the time-to-depth conversion was $0.167 \mathrm{~m} \mathrm{~ns}^{-1}$. The use of a single value of radar wave speed for the depth conversion is a simplification; it does not take into account the variation in wave speed through the firn nor any variation with depth due to temperature, though these variations are 
likely to change slowly in the horizontal direction. We are not able to quantify these variations, so the absolute elevations in the WGS84 ellipsoid reference frame may be in error to the order of 10-20 m, even though the relative heights of the landforms are known to $\pm 3 \mathrm{~m}$.

\subsection{Limitations of the data set}

There is an implicit assumption in the acquisition and processing of single-source, single-receiver radar data that the reflection point lies vertically beneath the centre of the antenna array. This assumption is invalid under a number of circumstances, some of which can be corrected, others not. For reflection points that lie in the vertical plane through the profile line, reflections (or diffractions from point sources) can arise from points ahead of or behind the radar. Because the process of moving the system along the line renders these in-line but off-nadir reflections into hyperbolae on the record, they can be corrected during the migration processing step. However for reflection points lying off-nadir to either side of the line, it is not possible to reconstruct the original source point without additional cross-track records. Over large areas of the present survey this does not matter because the topography of the bed is largely two-dimensional and the line orientation was chosen to be orthogonal. The exceptions are areas where the bed slopes significantly in the in-flow direction, such as at the upstream or stoss end of drumlins, the upstream end of the central high ridge and the hummocky area in the centre of the survey. The effect is to limit the ability to accurately map the shape and position of the rounded ends of drumlins, even though the cross-profiles of the features is precisely known. We have conducted check surveys with closer cross-track spacing in some of the areas of potential uncertainty and find that the cross slopes are sufficiently shallow that side echoes do not map onto the in-line profile at times earlier that the vertical return from the bed.

The radar wave speed profile through the ice column is not known, which means that values of ice thickness and therefore absolute bed elevation relative to sea level may have errors of circa $20 \mathrm{~m}$, hence the adoption of a single value for the average wave speed. This uncertainty in the absolute elevation has no impact on the primary objective of the survey, which was measurement and observation of subglacial landforms.

\section{Results - map products}

The bed elevation map is shown as Fig. 3; the same data, projected as a 3-D view, are shown in Fig. 4. On the large scale the bed has a $\mathrm{W}$ profile with troughs to either side separated by a central ridge. The central ridge is subdued in the upstream portion of the survey area (labelled "central low ridge" in Fig. 3 and much higher in the downstream portion ("central high ridge" in Fig. 3).

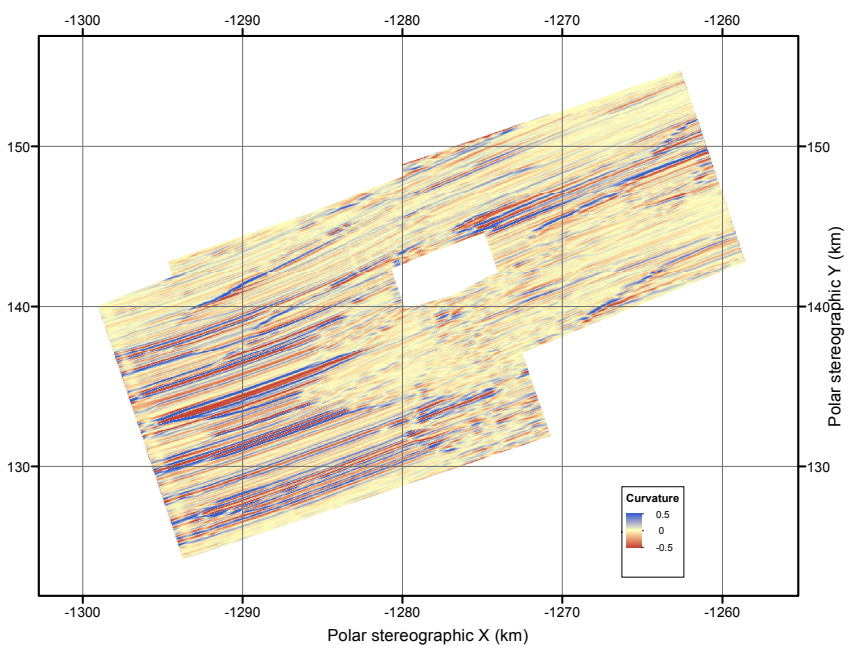

Figure 5. Map of the curvature of the bed elevation surface. This method of presenting the data emphasises the contrasts between high-amplitude linear features, low-amplitude linear features and low-amplitude features with low elongation. Positive values of curvature indicate upward convexity, and negative values upward concavity.

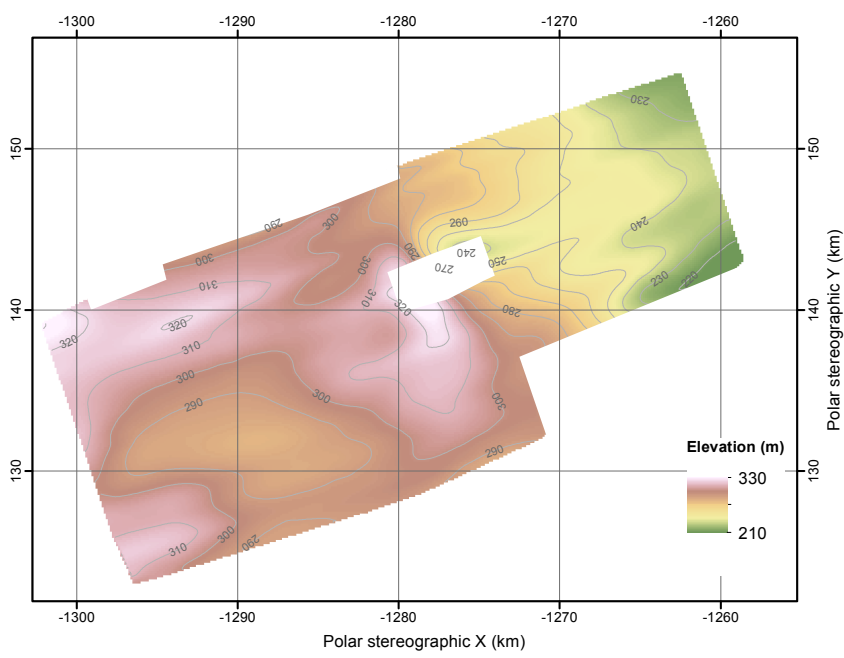

Figure 6. Map of the elevation of the surface of the ice stream referenced to the WGS84 ellipsoid. Data were collected using a dualfrequency GPS unit on the radar receiver sledge and post-processed using a kinematic technique (see text). Steepest surface slope occurs above the upstream end of the bedrock outcrop that forms the central high ridge at the bed.

In order to emphasise the smaller-scale landscape features, we applied a high-pass spatial filter to the data and then subtracted the filtered data from the original. The 3-D surface in Fig. 4 is colour-coded with the residual elevation to make the individual landforms more clearly distinguishable.

The curvature of the bed surface is shown in map form in Fig. 5. This display emphasises the difference between highly elongate linear features with sharply defined profiles, 


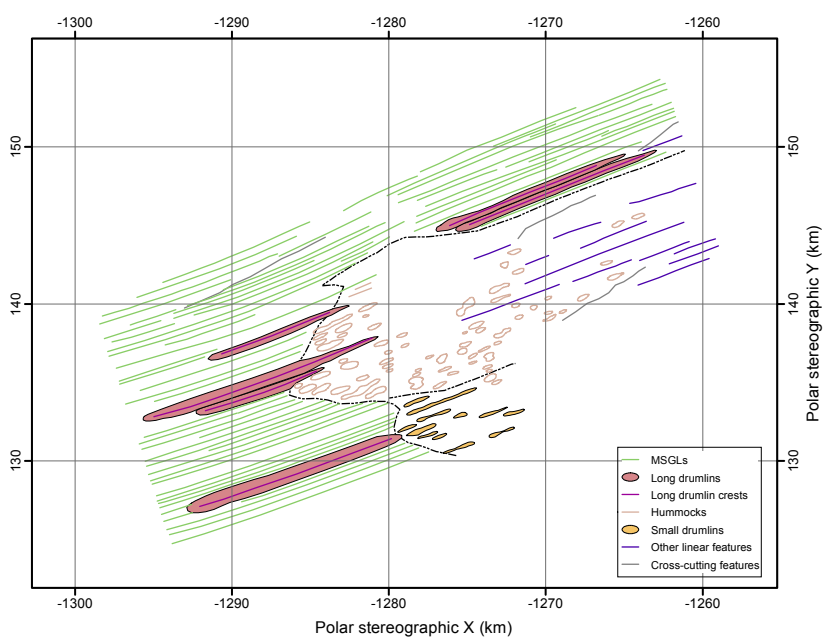

Figure 7. Geomorphological interpretation. The features of the bed of the ice stream can be classified into a number of different landforms and surface features, based on amplitude, length, outline shape and whether they are positive or negative landscape elements. See text for full descriptions of each class.

elongate but subdued features and subdued features with low elongation ratios. Curvature was calculated using a tool in ArcGIS that computes the second derivative value of the input surface on a cell-by-cell basis. A fourth-order polynomial is fit to a surface composed of a $3 \times 3$ window centred on the cell of interest; positive numbers indicate upward convexity, while negative numbers indicate upward concavity.

The surface elevation was derived from the dual-frequency GPS position information. Posted values at $7.5 \mathrm{~m}$ intervals along each survey line were used as input to create a surface model using convergent interpolation. The elevation in the upstream part of the survey is between 285 and $325 \mathrm{~m}$ above the WGS84 ellipsoid (Fig. 6), with no consistent downstream slope. A high point is reached near the centre of the survey, which lies above the upstream end of the central ridge seen on the bed. The surface elevation downstream of this high point drops relatively steeply (by $70 \mathrm{~m}$ over $2 \mathrm{~km}$ ) in the south-easterly direction.

There are several classes of subglacial bedform within the survey area (Fig. 7). A full description of the landforms will be presented elsewhere; here we summarise the main forms.

1. Parallel-sided MSGLs: the dominant features observed in the eastern trough are parallel-sided MSGLs which have large elongation ratios (i.e. great length, small width) and low amplitudes. These landforms are up to $17 \mathrm{~km}$ long and are spaced an average of 300 to $400 \mathrm{~m}$ apart (Spagnolo et al., 2014). In the NE trough, these features have a subtle kink in plan (Fig. 5), where they deviate toward the left (as viewed by an observer facing down flow) margin of the ice stream in the region of the step in the bed. Parallel-sided MSGLs in the SW
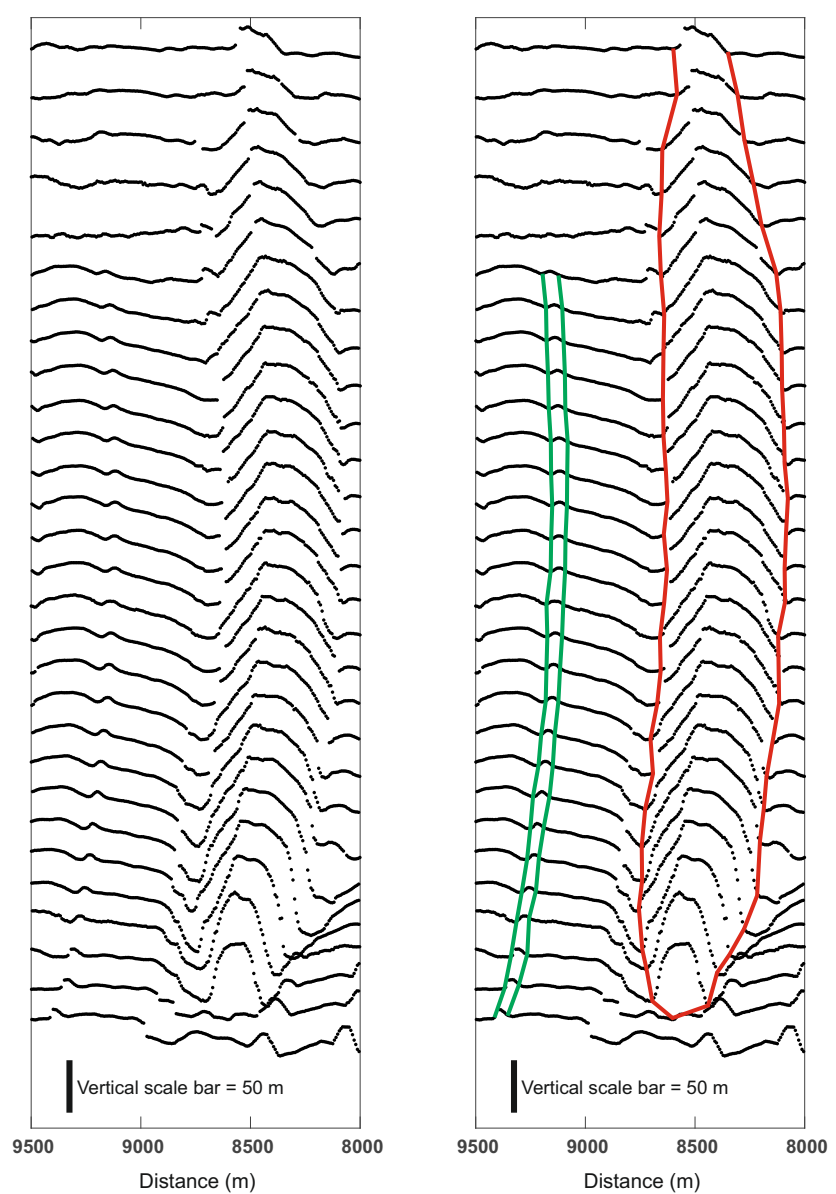

Figure 8. Elevation profiles from the crest of the central low ridge (Fig. 3) to illustrate the difference in cross section between parallelsided MSGLs (highlighted in green on the right-hand panel) and tapering drumlins (highlighted in red). The drumlin tapers in width at both ends and has a maximum vertical relief an order of magnitude greater than the MSGLs.

trough are continuous for about $16 \mathrm{~km}$ and terminate downstream at a sharply defined line.

2. Tapering drumlins: there are six features which lie within the field of MSGLs but which are distinctly different. These have higher trough-to-crest amplitudes (up to $70 \mathrm{~m}$ ); a crest line that rises steeply to a maximum near the upstream end then tapers slowly downstream. Usually the troughs to either side reach their lowest points adjacent to the highest point on the crest. The contrast between these features and the parallel-sided MSGLs is illustrated in Fig. 8, which shows portions of the bed elevation profiles picked from the radar profiles across part of the central ridge. The example drumlin tapers in width at each end and has much larger vertical relief than the adjacent MSGLs.

3. Small drumlins or hummocks: the central and westcentral parts of the survey are dominated by features 
Table 1. Projection: Antarctic polar stereographic, WGS84 ellipsoid, Prime Meridian 0.0, standard parallel $71^{\circ} \mathrm{S}$.

\begin{tabular}{lll}
\hline Axis & Min & Max \\
\hline$X$ & -1299211.26 & -1258669.79 \\
$Y$ & 124167.22 & 154725.41 \\
Depth [m] (below WGS84 ellipsoid) & -2185.76 & -1476.94 \\
Lat. & $78^{\circ} 23^{\prime} 51.3927^{\prime \prime} \mathrm{S}$ & $78^{\circ} 00^{\prime} 1.0350^{\prime \prime} \mathrm{S}$ \\
Long. & $84^{\circ} 32^{\prime} 26.7107^{\prime \prime} \mathrm{W}$ & $82^{\circ} 59^{\prime} 30.9101^{\prime \prime} \mathrm{W}$ \\
\hline Increment in $X$ direction: & 100 & \\
Increment in $Y$ direction: & 25 & \\
Unrotated $X$ min: & -1293677.31 & \\
Unrotated $Y$ min: & 124167.22 & \\
Unrotated $X$ max: & -1254477.31 & \\
Unrotated $Y$ max: & 143242.22 & \\
Rotation angle: & 18.6 & \\
Number of 2-D nodes in $I$ direction: & 393 & \\
Number of 2-D nodes in $J$ direction: & 764 & \\
& & \\
\hline Topography statistics & & $\mathrm{m}$ \\
Min: & -2185.76 & $\mathrm{~m}$ \\
Max: & -1476.94 & $\mathrm{~m}$ \\
Delta: & 708.82 & \\
Number of defined values: & 244280 & \\
Mean: & -1858.71 & \\
\hline & & \\
\hline
\end{tabular}

with low amplitude and small elongation ratios (Fig. 7). In the south-western trough there is a small group of drumlins that have higher amplitudes and longer elongation ratios but are distinct from the MSGLs and separated from them by a distinct boundary.

4. Other linear features: the high region in the southcentral part of the survey has few positive streamlined features; the linear features that do exist are mostly grooves. On the west flank of the topographic high there is a step approximately $40 \mathrm{~m}$ high which is oriented at an angle to the ice flow.

\section{Parameters for the gridded data set}

Details of the projection, limits and basic statistics of the data set are given in Table 1.

\section{Significance of the data set}

This data set provides an extensive, high-resolution view of the landscape beneath an active ice stream. It will be of interest to those wishing to calibrate the palaeo-record of ice stream tracks and to those seeking to understand the processes involved in generating subglacial landforms. All previous observations of fields of subglacial landforms have been from deglaciated regions; hence this data set will enable the testing of theories concerning dewatering and sediment consolidation during the process of deglaciation. Given that repeat seismic surveys within the area have shown rapid rates of both erosion and deposition, this data set forms a baseline survey for the assessment of sediment transport and landform evolution by way of repeat survey using similar techniques in the future. The data set also allows the size and spatial distribution of landforms to be compared to the metrics of palaeoexamples. The provision of the raw $x, y, t$ picks in the data set will facilitate precise re-survey and direct comparison of the raw data rather than the interpolated surfaces.

\section{Data availability}

The data set (King et al., 2015) can be accessed at: http://doi. org/269.

Acknowledgements. We gratefully acknowledge the field assistants, pilots and operations staff of the British Antarctic Survey's Rothera Station for their support during the field data collection. Schlumberger Limited is thanked for supplying educational licences for its Petrel software. This work was funded by BAS's Global Science in the Antarctic Context Programme (NERC award NE/B502287/1). We thank two reviewers and the editor for their assistance in clarifying this paper.

Edited by: O. Eisen 


\section{References}

Clark, C. D.: Emergent drumlins and their clones: from till dilatancy to flow instabilities, J. Glaciol., 56, 1011-1025, 2010.

Clark, C. D., Hughes, A. L. C., Greenwood, S. L., Spagnolo, M., and $\mathrm{Ng}, \mathrm{F}$. S. L.: Size and shape characteristics of drumlins, derived from a large sample, and associated scaling laws, Quaternary Sci. Rev., 28, 677-692, 2009.

Fowler, A. C.: The formation of subglacial streams and mega-scale glacial lineations, P. Roy. Soc. A-Math. Phy., 466, 3181-3201, 2010.

Fretwell, P., Pritchard, H. D., Vaughan, D. G., Bamber, J. L., Barrand, N. E., Bell, R., Bianchi, C., Bingham, R. G., Blankenship, D. D., Casassa, G., Catania, G., Callens, D., Conway, H., Cook, A. J., Corr, H. F. J., Damaske, D., Damm, V., Ferraccioli, F., Forsberg, R., Fujita, S., Gim, Y., Gogineni, P., Griggs, J. A., Hindmarsh, R. C. A., Holmlund, P., Holt, J. W., Jacobel, R. W., Jenkins, A., Jokat, W., Jordan, T., King, E. C., Kohler, J., Krabill, W., Riger-Kusk, M., Langley, K. A., Leitchenkov, G., Leuschen, C., Luyendyk, B. P., Matsuoka, K., Mouginot, J., Nitsche, F. O., Nogi, Y., Nost, O. A., Popov, S. V., Rignot, E., Rippin, D. M., Rivera, A., Roberts, J., Ross, N., Siegert, M. J., Smith, A. M., Steinhage, D., Studinger, M., Sun, B., Tinto, B. K., Welch, B. C., Wilson, D., Young, D. A., Xiangbin, C., and Zirizzotti, A.: Bedmap2: improved ice bed, surface and thickness datasets for Antarctica, The Cryosphere, 7, 375-393, doi:10.5194/tc-7-3752013, 2013.

Gades, A. M.: Spatial and temporal variations of basal conditions beneath glaciers and ice sheets inferred from radio echo soundings, PhD University of Washington, 1998.

Greenwood, S. L. and Clark, C. D.: The sensitivity of subglacial bedform size and distribution to substrate lithological control, Sediment Geol., 232, 130-144, 2010.

Gudmundsson, G. H.: Fortnightly variations in the flow velocity of Rutford Ice Stream, West Antarctica, Nature, 444, 1063-1064, 2006.

Gudmundsson, G. H. and Jenkins, A.: Ice-flow velocities on Rutford Ice Stream, West Antarctica, are stable over decadal timescales, J. Glaciol., 55, 339-344, 2009.

Joughin, I., MacAyeal, D. R., and Tulaczyk, S.: Basal shear stress of the Ross ice streams from control method inversions, J. Geophys. Res.-Sol. Ea., 109, doi:10.1029/2003jb002960, 2004.

King, E. C.: Flow dynamics of the Rutford Ice Stream ice-drainage basin, West Antarctica, from radar stratigraphy, Ann. Glaciol., 50, 42-48, 2009.

King, E. C., Woodward, J., and Smith, A. M.: Seismic and radar observations of subglacial bed forms beneath the onset zone of Rutford Ice Stream Antarctica, J. Glaciol., 53, 665-672, 2007.

King, E. C., Hindmarsh, R. C. A., and Stokes, C. R.: Formation of mega-scale glacial lineations observed beneath a West Antarctic ice stream, Nat. Geosci., 2, 585-588, 2009.

King, E. C., Pritchard, H. D., and Smith, A. M.: Rutford Ice Stream bed elevation DEM from radar data, Cambridge, UK, available at: https://legacy.bas.ac.uk/dms/full-record.php? $\mathrm{id}=\mathrm{GB} / \mathrm{NERC} / \mathrm{BAS} / \mathrm{PDC} / 00813$ (last access date: 30 March 2016), 2015.
Larter, R. D., Graham, A. G. C., Gohl, K., Kuhn, G., Hillenbrand, C. D., Smith, J. A., Deen, T. J., Livermore, R. A., and Schenke, H. W.: Subglacial bedforms reveal complex basal regime in a zone of paleo-ice stream convergence, Amundsen Sea embayment, West Antarctica, Geology, 37, 411-414, 2009.

Lindsey, J. P.: The Fresnel zone and its interpretive significance, The Leading Edge, 8, 33-39, 1989.

MacAyeal, D. R., Bindschadler, R. A., and Scambos, T. A.: Basal Friction of Ice-Stream-E, West Antarctica, J. Glaciol., 41, 247262, 1995.

Menzies, J.: Drumlins - Products of Controlled or Uncontrolled Glaciodynamic Response, Quaternary Sci. Rev., 8, 151-158, 1989.

Rose, J.: Drumlins as part of a glacier bedform continuum, edited by: Menzies, J. and Rose, J., Drumlin Symposium, Rotterdam, Balkema, 360 pp., 1987.

Smith, A. M.: Basal conditions on Rutford Ice Stream, West Antarctica, from seismic observations, J. Geophys. Res.-Sol. Ea., 102, 543-552, 1997a.

Smith, A. M.: Variations in basal conditions on Rutford ice stream, west Antarctica, J. Glaciol., 43, 245-255, 1997 b.

Smith, A. M.: Microearthquakes and subglacial conditions, Geophys. Res. Lett., 33, L24501, doi:10.1029/2006GL028207, 2006.

Smith, A. M.: Subglacial bed properties from normal-incidence seismic reflection data, J. Environ. Eng. Geoph., 12, 3-13, 2007.

Smith, A. M. and Murray, T.: Bedform topography and basal conditions beneath a fast-flowing West Antarctic ice stream, Quaternary Sci. Rev., 28 584-596, 2009.

Smith, A. M., Murray, T., Nicholls, K. W., Makinson, K., Aoalgeirsdottir, G., Behar, A. E., and Vaughan, D. G.: Rapid erosion, drumlin formation, and changing hydrology beneath an Antarctic ice stream, Geology, 35, 127-130, 2007.

Spagnolo, M., Clark, C. D., and Hughes, A. L. C.: Drumlin relief, Geomorphology, 153, 179-191, 2012.

Spagnolo, M., Clark, C. D., Ely, J. C., Stokes, C. R., Anderson, J. B., Andreassen, K., Graham, A. G. C., and King, E. C.: Size, shape and spatial arrangement of mega-scale glacial lineations from a large and diverse dataset, Earth Surf. Proc. Land, 39, 1432-1448, 2014.

Stokes, C. R. and Clark, C. D.: Are long subglacial bedforms indicative of fast ice flow?, Boreas, 31, 239-249, 2002.

Storrar, R. and Stokes, C. R.: A Glacial Geomorphological Map of Victoria Island, Canadian Arctic, Journal of Maps, 191-210, 2007.

Welch, B. C. and Jacobel, R. W.: Analysis of deep-penetrating radar surveys of West Antarctica, US-ITASE 2001, Geophys. Res. Lett., 30, doi:10.1029/2003g1017210, 2003.

Yilmaz, O.: Seismic data processing, Tulsa, Society of Exploration Geophysicists, 1987. 